\title{
Red Dog, Horses and Bogong Moths: The Memorialisation of Animals in Australia
}

\author{
ROSE SEARBY
}

Bill and the vet buried the Red Dog in a simple grave in the bush between Roebourne and Cossack. They laid him in that stony red earth and covered him over. It was a hot day, a day when Red might otherwise have been lounging in the air-conditioned mall at Dampier, or taking the ore train to Mt Tom Price. There is no-one now who remembers where that grave was, and no headstone was ever placed above it. His friends eventually raised a bronze monument to him in Dampier, but otherwise there is nothing left of Red Dog but the stories, and his collar, whose tag reads 'Red Dog-Bluey' on one side, and 'I've been everywhere, mate' on the other. ${ }^{1}$

\footnotetext{
fter seeing the statue of Red Dog in the Western Australian town - 1 of Dampier, Louis de Bernière was inspired to collect stories about this red kelpie, cattle dog cross who travelled around as he
} 
pleased. The passage quoted above reflects much about how animals are memorialised in Australian history. Memorialisation does not only take a material form but may be revealed and celebrated through intangible forms such as stories, myths, ceremonies and festivals. This is not to say that tangible or material memorials to animals do not exist. Rather, they constitute more traditional forms of memorialisation and often reflect the 'cultural landscape of humans' more than the animal itself.

This article investigates the idea of an intangible memorial through a focus on two particular animals: horses in the Snowy Mountains region of New South Wales (NSW) and Bogong moths (Agrotis infusa), insects which have a long history of relations with Aboriginal people prior to the colonisation of Australia. In doing so I explore what intangible memorialisation of animals might look like, what forms it may take and how it reflects relations between humans and animals. The various ways animals are remembered show that the memorialisation of animals is not straightforward and requires broader ways of thinking about the animals themselves than more traditionally recognised (or material) notions of memorialisation allow. These broader ways of thinking invite a repositioning of animals in relation to humans in order to see the memorial landscape as co-constructed by both humans and animals, thus facilitating the rethinking of a framework for memorialising animals. ${ }^{3}$

In order to explore the memorialisation of animals in Australia, this article links what may initially appear as two unlikely nonhumans - the horse and the Bogong moth. Both have particular significance to the Snowy Mountains region of NSW, the geographic area from which my two case studies are drawn. While the Bogong moth is an insect and member of the Lepidoptera species (moth or butterfly) and thus not strictly an animal, it, like horses, is relevant to a study of memorialisation because of its historic, cultural and environmental significance in Australia. Further, the inclusion of Bogong moths is also a response to the call from scholar Eric Brown for more studies of animals to focus specifically on insects and for insects to be integrated into animal studies more generally. ${ }^{4}$

At the heart of ideas about the memorialisation of animals lie questions about the human representation of them and, in a broader context, human relations with nature. These are debates which are at the core of the emerging field of animal studies and concern for many 
scholars a determination to dissolve the dualism between nature and culture. This stemmed largely from Cartesian philosophy that saw animals as merely machines: mindless, soulless and incapable of conscious thought, ${ }^{5}$ as well as a desire for nature to gain a degree of agency. ${ }^{6}$ Understanding the broad origins of animal studies and the development of human-animal relations in Western societies is important in relation to memorials and the process of memorialisation because it brings animals to the forefront of thought and challenges us to find ways to focus the memorialisation process on animals themselves.

Hilda Kean claims that the memorialisation of animals may say more about humans than the animals themselves, citing the British example of sculptures of thoroughbred dogs which serve to confer status on their owners. ${ }^{7}$ Similarly, there are numerous memorials to animals in Australia which confirm Kean's argument and, importantly, also illustrate how traditional material forms of memorials may be seen as anthropocentric - or human-centred - in nature. Memorials such as those to the Cactoblastis cactorum moth, insects that were imported into Queensland in 1925 to successfully eradicate the prickly pear, are indicative of collective community values about the environmental and the economic importance of land. The array of memorials including outdoor cultural objects, a stone obelisk and the naming of the Boonarga Cactoblastis Memorial Hall reflects the indebtedness of the Queensland people to the Cactoblastis moth for eliminating the introduced invasive species of prickly pear (though Queenslanders would later have to import cane toads, now a major environmental problem, to rid themselves of the moths). ${ }^{8}$

In a similar way, the bronze statue of Il Porcellino, or 'Wild Boar', sitting alert and poised in Sydney's Macquarie Street exemplifies the anthropocentric aspects of material memorials to animals. Il Porcellino was presented to the city in 1968 by the Florentine Marchesa Fraschi Torrigiani in memory of both her surgeon brother and father who worked at the Sydney Hospital. The boar is a replica in form and function of a Hellenistic marble boar in Florence's Uffizi Gallery which acts as a wishing well to those who leave money. ${ }^{9}$ In reflecting the landscape of humans, memorials such as Il Porcellino and those to the Cactoblastis cactorum moth act as material remains from which we can interpret the past. ${ }^{10}$ Yet the boundaries of such interpretations are 
specifically human, fixed as they are to specific events or people and interpreted through an anthropocentric framework: these material memorials privilege humans over animals.

The existence of more traditional, material memorials raises questions about what other types of memorials to animals might exist and how we may be able to think of a memorial if it is not of a tangible nature, has no physicality about it and cannot be experienced and 'felt' through touch. In order to consider these kinds of questions we need to firstly shift any anthropocentric framework of reference for how we 'see' memorials and instead make animals the centre of the memorialisation process.

One way of doing this is to recognise the memorial landscape as co-constructed by humans and animals, something that can enable a repositioning of animals in relation to humans and result in the creation of a new framework of reference for memorialising animals. To do so reminds us of cultural geographer Lesley Instone's challenge to make 'the hitherto unthinkable possibilities of different geographies [that] celebrate inclusion, difference, multiplicity, dissonance and change'. ${ }^{11}$ By achieving what might have once been considered 'unthinkable' we can recognise the alternative shapes and forms animal memorials may take and acknowledge ways of remembering animals that focus on them as the centre of the memorial process, not only as statically represented in the material form.

Louis de Bernière's stories about Red Dog are an example of how animals may be memorialised in ways other than the material, and how memorials of animals can be conceived of as intangible something that is not cemented to a specific memory or event. In the case of Red Dog it is the stories of his life and travels, as well as his relations with those he befriended - both human and non-human that may be considered a type of memorial. These stories derive from memories that are not fixed but rather represented in a form which is defined and expressed through experience and emotion and reflects collections of memories over time. To conceive of an intangible memorial therefore is to think about ways in which animals are remembered through stories. This form of memorialisation can take on significant meanings when situated in different cultural, social and/or environmental narratives.

In order to conceptualise how memorials may be considered intangible, I turn to geographer Kenneth Foote's term of a 'living' 
memorial as one that is not solely material ${ }^{12}$ and Virginia Woolfe's writings about 'life'. Both Foote and Woolfe's ideas about 'living' and 'life' offer a springboard from which to think about the meaning of an intangible memorial as the following passage from Woolfe suggests:

What he could do he did. Watching him, it seemed as if a fibre, very thin but pure, of the enormous energy of the world had been thrust into his frail and diminutive body. As often as he crossed the pane, I could fancy that a thread of vital light became visible. He was nothing but life. ${ }^{13}$

Virginia Woolf was obsessed with capturing 'life' in her writing and believed that lepidoptera (moths and butterflies) ideally represented life. ${ }^{14}$ Lepidoptera were a key trope in Woolf's work, something which was linked with her pursuit of bug hunting. She believed that to literally 'pin' down insects only narrowly defined reality and was antithetical to the unconstrained nature of life. As a metaphor for her own writing, Woolf believed that pinning down insects - as with pinning down words - left one with a 'stiff lifeless shell of the original item remaining to be preserved' ${ }^{15}$

Thinking about memorials beyond the boundaries of the human enables us to see memorials to animals as more than material statues which can be felt and touched, different to objects of tangible heritage which can be 'pinned' down by static representations of them, and not restricted by the representation of animals solely through text. The implications of Woolfe's writing for ideas about intangible memorials to animals are that the very nature of animals - or more broadly in the words of Sarsfield who describes Woolf's work, the 'unconstrained nature of life' - must be reflected in the way animals are memorialised: as living memorials which are felt and defined through experience, emotion, stories, ceremony and festival.

\section{THE INTANGIBLE MEMORIALISATION OF HORSES}

At one end of Centennial Park in Sharpe Street, Cooma, is a bronze statue of a man riding a horse. A tribute to the 'Man from Snowy River', a figure immortalised in A. B. ('Banjo') Paterson's poem of the same name, the statue is quite small in size and stands atop a tall slab of granite about eight feet or so from the ground. Executed by Australian sculptor and architect Ian McKay, it was unveiled in 


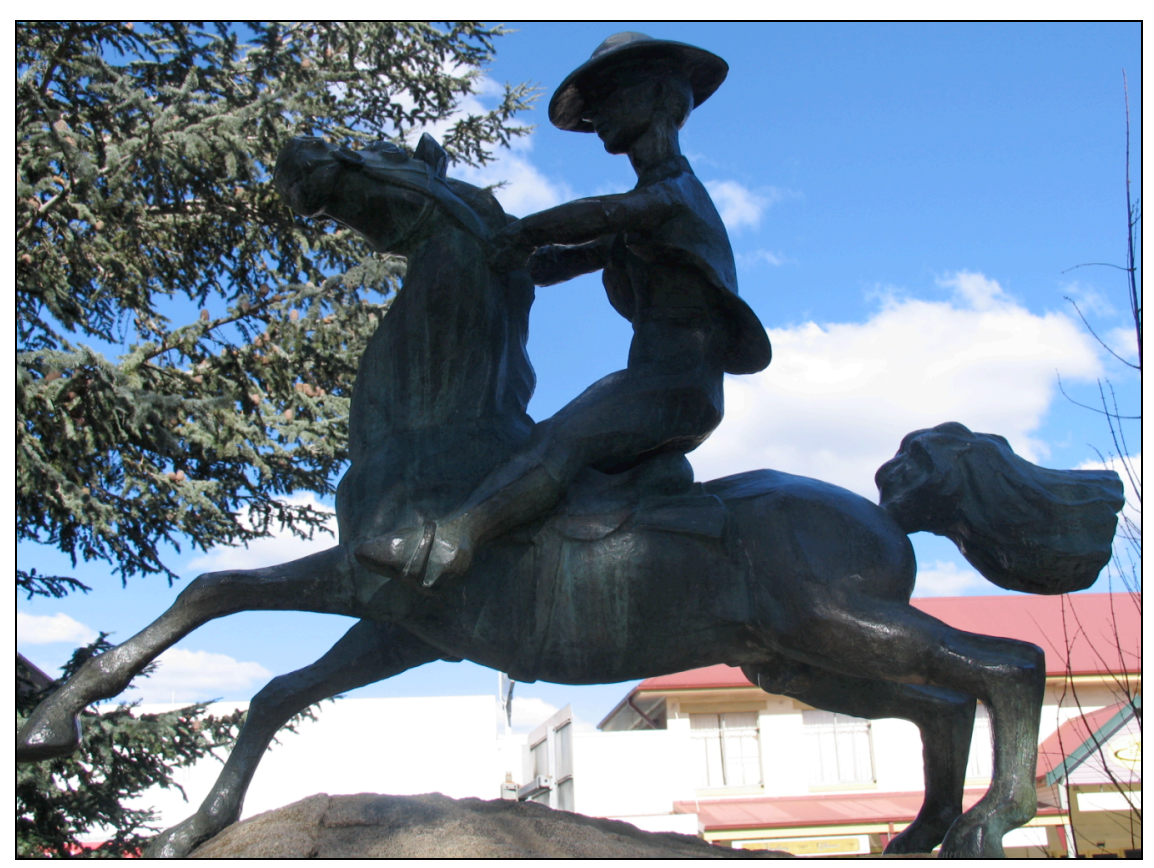

The Man From Snowy River statue in Cooma, NSW, August 2006 (Photograph Rose Searby)

October 1961 for the '5th Festival of the Snows'. To the pastoral community of NSW's Snowy Mountains and other locals, the Man from Snowy River is a skilled and heroic bushman who represents a pastoral heritage that is an important and significant part of their own and Australia's cultural heritage. Due to its positioning, the monument reflects a reverence to the myth of the Man from Snowy River, for the height of the overall statue ensures it must be looked up to. The viewer, neck craned skywards, feels the openness of the sky which acts as a backdrop reflecting the freedom and movement of man and horse.

When approaching Cooma from the north the statue of the Man from Snowy River acts as a marker in the landscape indicating to its audience that they have entered the country of the 'Man'. Heavily laden with symbolic cultural meaning, the statue may evoke Paterson's poetry or Elyne Mitchell's children's stories, or for others, George Miller's 1982 film The Man From Snowy River. An integral part of these images is both the domestic and the wild horse, without which the cultural imagining of the Man from Snowy River would not exist. Thus the statue represents a landscape saturated with intangible memorials to the enigmatic figure and his horse. Here, 
both human and animal play an equal part in the creation of the myths, stories and legends which are a form of memorialisation that does not concern death but instead represents a form of remembering which has evolved over a century. Such remembering is integrally connected with the wider cultural, political and environmental narratives surrounding humans and horses in the Snowy Mountains which express the heritage and identity of pastoralists and recreational horse-riders in the context of belonging and conflict over access to high-country grazing land.

Lisanne Gibson and Joanna Beasley claim that men on horses represent one of the most traditional forms of public art. ${ }^{16}$ Certainly statues of horses abound in Australia holding the likes of kings (such as King George V on a horse in Brisbane's King George Square erected in 1938) ${ }^{17}$ and bushrangers (including Thunderbolt the bushranger and his horse in Uralla erected in 1988). ${ }^{18}$ However, the focus of many of these works is not on the horse but the human and the relationship between human and horse for the most part remains unexposed. This is exemplified by the absence of any explanation of relations on the interpretative plaques of these statues. Yet there may often be an integral connection between human and horse that is unacknowledged or not considered relevant. And in these cases, a connection may only be revealed by shifting the focus of the memorial to the horse and considering the animal as an equal part of the memorial landscape.

The following example illustrates how examining relations between horse and rider can reveal stories about the animal which position it as an essential part of a landscape that is co-constructed by humans and animals. In August 2005, around 500 pastoralists rode their horses to Parliament House in Melbourne to campaign against the proposed ban of horses from Victoria's high-country in a demonstration against a pending decision by the Victorian State government not to renew grazing leases in Alpine National Park. The pastoralists claimed that their heritage and way of life would be destroyed if they were not allowed access to grazing land within the national park. 'It's a tradition', they declared. 'You don't just kick a 170-year tradition out of the bush just for one little management issue' ${ }^{19}$ The pastoralists argued that Australian culture and heritage were at stake and in doing so positioned themselves as an essential part of the country's history - part of a 'pioneer heritage' where 
'everywhere in someone there's a man from Snowy River' ${ }^{20}$ The language used and emotions expressed by those on the steps of Parliament House came directly from Paterson's poem which immortalised the horseman/pastoralist. ${ }^{21}$

This representation of the horse as an integral part of the image of the Snowy Mountains horsemen also continues to find expression in contemporary advertising, film and marketing. The milk carton of the Snowy Mountains Organic Dairy Company, for instance, dedicates a panel of its packaging to Jack Riley, the man many claim to be 'The Man From Snowy River' and the inspiration for Paterson's poem. 'He not only gained notoriety for his "ride"', the carton reads, 'but also as a horseman, bushman and horse breaker... the legend continues to this day. ${ }^{22}$

The façade of reverence which the audience is forced to create with their bodies as they crane their necks to look up at the statue of the Man From Snowy River in Centennial Park, Cooma, hides the narratives of conflict and contestation that surround both the material and intangible memorials to the Man From Snowy River, narratives that found expression in the pastoralists' protest. Yet these narratives are also a construction of the past that reflect relations between animals and humans. At the heart of the conflict for many pastoralists and recreational horse riders lies an even deeper narrative which establishes an integral relationship between horse and rider.

In Australia, memorials are often linked to cultural heritage preservation. As Paul Ashton and Paula Hamilton observe in their article in this volume of the Public History Review, the thematic frameworks adopted for identifying and assessing memorials for listing shape the content of heritage registers. ${ }^{23}$ Thinking about the memorial landscape as co-constructed by animals and humans in order to recognise how the memorialisation of animals can be intangible can inform heritage and offer ways of thinking about heritage that is inclusive of cultural, social and environmental elements which may not fit neatly, or at all, into current heritage definitions and registers. Instances where this has been tested illustrate that preserving intangible memorials to animals as part of cultural heritage challenges existing heritage structures. This occurred in a case where the Snowy Mountains Horse Riding Association (SMHRA) proposed the heritage listing of an area of 
national park land in a claim that was largely about relations between horse and rider.

In 2005, SMHRA made a claim in the form of an urgent request to the Minister for Environment and Heritage that an area of Kosciuszko National Park and Victoria's Snowy River National Park be included in the National Heritage List. This came about in reaction to what SMHRA believed to be increasingly restrictive management plans for access for horse riders to both National Parks. SMHRA felt that this denied both horse and rider their place in the Australia's heritage. In its submission SMHRA claimed that:
... SRNP (Snowy River National Park) and KNP
(Kosciuszko National Park) have outstanding heritage value to the nation for their demonstration of a tangible part of Australia's cultural history relating to the story of the Man from Snowy River, summer seasonal horse- riding as part of mountain grazing and associated cultural practices... SMHRA claims that this cultural heritage is nationally rare... and endangered by current and proposed management of Parks. ${ }^{24}$

SMHRA's request for heritage listing may be seen as an expression of desire not only to assert but formalise relations between horse and rider. But the horse-riding community was restricted by the lack of heritage criteria that could be applied to human-animal relations in Australian history. In order to support its claim SMHRA used myths and stories by literary figures such as Banjo Paterson and Elyne Mitchell to define place and legitimise the association of the horses with it. ${ }^{25}$ The request for heritage listing was denied by the NSW Government which concluded that the regulation of horse-riding activities was not a threat to potential national heritage values ${ }^{26}$ and that SMHRA's application was 'deficient in detail as to why place was significant for horse-riders'.$^{27}$

In reply to the findings, SMHRA accused the Heritage Office of failing to 'understand the nature of the request' ${ }^{28}$ Indeed, the 'nature' of the request was multifaceted and in making such a submission SMHRA attempted to present over a century's history of humanhorse relations and associate these relations with place - a complex task. In associating horses and horse-riding with the cultural heritage of the Snowy Mountains, SMHRA not only stressed the inseparable 
relationship between horse and rider but also the notion that it is through the horse that the recreational rider and pastoralist know their land.

The story of SMHRA's failed claim for listing illustrates the challenges inherent in defining intangible memorialisation and linking animals into issues of cultural heritage. In a broader context, the story reveals a connection between the development of animal studies - that is in this case recognition that animals can have agency and play an important part in history - and the rise of histories of the senses and emotions. This connection has facilitated not only a closer relationship between humans and animals, as exemplified by the relationship between horse and rider in the Snowy Mountains case, but a more conscious one also.

\section{MeMORIALISING Bogong MothS THROUgh CEREMONY}

As shown through Red Dog and horses, seeing the memorial landscape as co-constructed by both humans and animals helps us to conceive of how memorialisation of animals can be intangible. Memorials are not only material markers in the landscape but change over time in relation to how they are experienced. They may act as a bridge through time, mediating the transformation of ancient rituals or ceremonies into more modern ones.

In his discussions of ritual, Paul Connerton argues that commemorative ceremonies are preserved versions of the past which keep the past in mind and are expressed in and through the body. For Connerton, 'we can preserve the past deliberately without explicitly re-presenting it in words and images'. ${ }^{29}$ And it is historians who need to interpret ritual and reinstate it in its historical context rather than merely reading ritual as a self-contained text. ${ }^{30}$ It is in this light that activities and events which are practised through time may become memorialised in ceremonies and festivals that are focused on animals. $^{31}$

The Bogong moth was celebrated through ceremony by Aboriginal people prior to the European colonisation of Australia. Bogong moths are brown insects with a wingspan of about four centimetres. They appear throughout non-tropical Australia but only seem to migrate in the southeast. ${ }^{32}$ Their presence in the high country of the Snowy Mountains and the Victorian Alps represents one of the longest insect migrations in the world. ${ }^{33}$ The moths migrate as a 
response to hot harsh conditions in the north of Australia and travel over one thousand kilometres south to cooler conditions and high altitudes. ${ }^{34}$ They are one of only a few species of lepidoptera which migrate twice, flying to a particular destination and then returning to the same destination (if they have survived) some four months later. The breed then repeats the same cycle again in subsequent seasons.

On their arrival in the Alps the moths group together in their millions in deep dark crevices in rock caves among granite boulders where the temperature and humidity are fairly constant. Their aestivation occurs over the summer months in caves that often become permanent camps to which the moths return each year. ${ }^{35}$ Bogong moths store up to sixty per cent of their body weight as fat in their abdomen. Not only do these fat reserves sustain the moths during their long flights to the mountains - some moths do not feed at all during this time. ${ }^{36}$ But historically they also served to provide Aboriginal people, and some animal species, with a nutritious food source.

It is widely accepted that Bogong moths were/are a vital food source for Aboriginal people. What is debated, however, is the role of the Bogong moth as an important subject of ceremony. It is these ceremonial aspects that may be considered a particular way of memorialising the insect while at the same time shedding light on the moths' relations with humans over centuries. Each year the ceremonial aspects of the Bogong moth are enacted in the Ngan-Girra Festival, formerly known as the Bogong Moth Festival. Held in Albury, NSW, its purpose is to celebrate the heritage and culture of the gatherings of Aboriginal tribes for feasting on the moths. ${ }^{37}$ While festivals have a role in celebrating specific cultural and physical aspects of regions - in creating a particular understanding of place and reflecting a community's sense of itself - the Ngan-Girra Festival represents more than this. ${ }^{38}$ It is also a way of memorialising the Bogong moth in its ceremonial form, merging real and imagined histories of humans and animals whose relations stretch back many millennia.

The ceremonial purposes surrounding the Bogong moth, however, have been debated in Australian history ever since the Reverend William Branwhite Clarke made reference to Bogong moths in his account of his trip to the Snowy Mountains region in 1852. He reported that: 
The Blacks had visited the Snowy Mountains, a short time previously to us, for the purpose of getting 'Bogongs' (Footnote: these moths have obtained their name from their occurrence on the 'Bogongs' or granite mountains, they were described by my friend Dr. Bennett... as abundant on the Bogong Mountain, Tumut River. I found them equally abundant, and in full vigour, in December, coming in clouds from the hollows of the granite peaks of the Muniong Range. The blacks throw them on the fire and eat them. W.B.C.). ${ }^{39}$

Despite current reservations by some members of the NSW National Parks and Wildlife Service about the cultural naivety and subjectivity illustrated in Clarke's accounts, his reports form an important record of the post-contact Aboriginal period and, significantly, contain some of the few existing written references to Bogong moths from this time. ${ }^{40}$

Clarke's account of the moths indicates the importance of them as a source of food and nutrition for Aboriginal people and is the generally accepted European representation of the moths: as migratory insects which are historically significant as a food source and therefore the reason for the seasonal migration of Aboriginal people to the high country. Such views have been further reinforced in the twentieth-century representation of the Bogong moth by the archaeologist Josephine Flood, who, in her seminal work The Moth Hunters: Aboriginal Prehistory of the Australian Alps, argues that the main purpose of Aboriginal people's journeys into the high country in summer was solely to feast on Bogong moths. ${ }^{41}$

Others, however, have questioned that the sole focus of moth feasting was purely for food. The conservationist Roger Good, for instance, suggests that the Bogong moth provided an important activity which was reserved for ceremonial functions. Good bases his argument on the fact that the scientific and cultural significance of favoured sites, times of occupation and activities undertaken by Aboriginal people in the Alps remain issues of debate. And he questions whether Flood's 'moth hunters' could in fact be 'possum hunters', as European accounts from the early nineteenth century tell of Aboriginal people in possum-skin clothing, raising the possibility that moths were not the only important part of their diet. ${ }^{42}$ 
The suggestion that Bogong moths were the subject of ceremonial importance is also raised by the environmental historian George Seddon who, like Good, questions Flood's focus on the moths as food being the sole reason for the pilgrimages. Seddon notes that Flood's picture of the Aboriginal people's movement from winter camps to a base camp closer to their pathways up to the Alps, and then up to the high country in summer, comprised a migration that was seasonal. However, there is no evidence, he argues, that the winter or base camps were vacated outside summer and may in fact have been inhabited all year round. ${ }^{43}$ The questions raised by Flood's hypothesis on the role of the moths by no means diminish the importance of her work on the prehistory of the Australian Alps. Yet these questions have brought to light the significant ceremonial role of the Bogong moth in Australian history.

The involvement of ceremony in the seasonal migration of Aboriginal people to the high country is also raised by Michael Young and Ellen and Debbie Mundy who refer to the 'Festival of the [sic] Bugong Moth', a festival for which the moth was the subject of cult totemism. ${ }^{44}$ Further confirming this, a 1949 letter from the supervising inspector of the Monaro Acclimatisation Society, R. Forrester Payten to Albert Sherbourne Le Souef, provides an account of the 'Festival of the [sic] Bugong Moth'. In it Payten indicates that in order to make their pilgrimages to the high-country, Aboriginal groups and tribes crossed the usual fixed tribal boundaries and held ceremonial meetings with other groups in the mountains:

... corroborees were held, followed by a further corroboree when the next group was encountered. Different groups from the coast were known to have met at Kalkite and after a corroboree these travelled together to Snowy Plain where a further corroboree celebrated the meeting of another group from Braidwood. ${ }^{45}$

Payten does note in his correspondence that 'the exact nature of this ceremony and its significance can only be surmised'. He also expresses his disappointment with the reliability of the evidence collected for his account, noting that dependable information 'at this late stage is very hard to get'. Yet Payten's letter leaves no doubt as to the importance of the ceremonial aspects related to the Bogong moth. They indicate that the reasons for the initiation and performance of 
ceremonies were far more complex than would be suggested by the simple hunting the moths as a food source. ${ }^{46}$

Contemporary accounts from Aboriginal people of the Snowy Mountains confirm that the Bogong moth was the subject of significant ceremonial activities as the following account from Vince Bulger illustrates:

This river here that we're lookin' at now is the Tumut River. And it's the most important to Aboriginals because it was the meeting place of all people, all tribal areas. They'd meet here, men, women and children, to go up into the Bogong Mountains... They'd come from all directions... to walk up into the mountains to celebrate the feasting of the Bogong moth. ${ }^{47}$

In speaking of the importance of the mountains as a gathering place for Aboriginal people to celebrate the moths, Vince Bulger's stories legitimate past ceremonial images of the Bogong moth and preserve them in the present. Thinking about his narrative in relation to the annual Ngan-Girra Festival shows both the importance of rituals associated with the moth over time and, despite changes in form of these rituals, and how insects and animals more generally can be memorialised through the representation of past events.

\section{CONCLUSION}

This article has examined ways in which animals are memorialised in Australia, both through material and intangible forms. In doing so it shows that there is a need for a shift in existing anthropocentric frameworks of reference for how memorials are seen in order to make animals the centre of the memorialisation process. By examining the narratives surrounding human-horse relations in the Snowy Mountains of NSW and ceremonies for Bogong moths, and touching upon the stories of Red Dog, I show how the intangible can be considered a memorial and a memorial landscape conceived of as something that is co-constructed by humans and animals.

Understanding memorialisation as intangible facilitates a repositioning of animals in relation to humans and the creation of a new framework of reference for memorialising animals. Such a framework of reference gives rise to exciting ideas as to how the memorialisation of animals may be considered in the future. Cultural 
heritage could more fully encompass and formally recognise intangible animal memorials. The methodological challenges inherent in shifting the focus of memorials to animals and beyond the boundaries of the human require further investigation. Finally, the framework suggested in this article could be applied to other types of animal memorials such as those to pets, on-line memorials to animals and memorial ceremonies to animals used in scientific research.

\section{ENDNOTES}

${ }^{1}$ Louis de Bernières, Red Dog, Secker \& Warburg, London, 2001, p115.

${ }^{2}$ Hilda Kean, 'An Exploration of the Sculptures of Greyfriars Bobby, Edinburgh, Scotland, and the Brown Dog, Battersea, South London, England', in Society \& Animals: Journal of Human-Animal Studies, vol 11, no 4, 2003 (online). Available: http:/ / www.psyeta.org/sa/sa11.4/kean.shtml (accessed 18 February 2008).

${ }^{3}$ The author would like to thank Professor Michele Dominy and Dr Hilda Kean for their helpful comments in their capacity as anonymous referees for this article.

${ }^{4}$ Eric C. Brown (ed), Insect Poetics, University of Minnesota Press, Minneapolis and London, 2006, px. Examples of studies that do focus on insects are: Marion Copeland, Cockroach, Reaktion Press, USA, 2004 and a special two volume issue entitled Insect Poetics, Antennae, issue 3, vol 1 and 2, Autumn 2007.

${ }^{5}$ James Serpell, In the Company of Animals: A Study of Human-Animal Relationships, Basil Blackwell, London and New York, 1989, p124.

${ }^{6}$ Val Plumwood, Feminism and the Mastery of Nature, Routlegde, London and New York, 1993, p5.

${ }^{7}$ Hilda Kean, op cit, no page given.

${ }^{8}$ Lisanne Gibson and Joanna Besley, Monumental Queensland: Signposts on a Cultural Landscape, University of Queensland Press, Queensland, 2004, p79.

${ }^{9}$ Michael Hedger, Public Sculpture in Australia, Craftsman House, Sydney, 1995, pp62-3.

${ }^{10}$ Jane Lydon and Tracey Ireland (eds), Object Lessons: archaeology and heritage in Australia, Australian Sccholarly Publishing, Melburne, 2005, p2.

${ }^{11}$ Lesley Instone, 'Situating Nature: On Doing Cultural Geographies of Australian Nature', Australian Geographer, vol 35, no 2, July 2004, pp131140.

${ }^{12}$ Kenneth E. Foote, op cit, p341.

${ }^{13}$ Virginia Woolfe, The Death of the Moth and Other Essays, originally published in 1942. Available: http:/ / ebooks.adelaide.edu.au/w/woolf/virginia/w91d/ (accessed 7 March 2008).

${ }^{14}$ Rachel Sarsfield, 'From the Chrysalis to the Display Case: The Butterfly's "Voyage Out" in Virginia Woolf', in Eric C. Brown (ed), op cit, pp87-111.

${ }^{15}$ ibid, p105.

${ }^{16}$ Gibson and Beasley, op cit, p13. 
${ }^{17}$ ibid, p13.

${ }^{18}$ Hedger, op cit, p61.

${ }^{19}$ Rachel Carbonell, Thursday 9 June 2005, ‘Cattlemen Fight for Alpine Grazing Rights', $A B C$ Online. Available: http:// www.abc.net.au/pm/ content/2005/s1388795.htm (accessed 12 December 2005).

${ }^{20}$ Melissa Marino, 6 May 2005, 'Colts and Old Regrets', in The Age (online). Available:

http:// www.theage.com.au/text/articles/2005/05/05/115092630236.html (accessed 12 December 2005).

${ }^{21}$ The Best of Banjo Paterson, introduction by Bruce Elder, Murray Child and Company, NSW, 1996, final verse, p46.

${ }^{22}$ The full passage on the panel of the one-litre milk carton from the Snowy Mountains Organic Dairy Company reads:

'The Man From Snowy River - Jack Riley. The town of Corryong is the resting place of THE MAN FROM SNOWY RIVER. Jack Riley was the inspiration for the A.B. Patterson epic poem. Jack migrated from Ireland in 1851 and lived in the Murray region until his death in 1914. His famous ride took place whilst he was manager of the Tom Groggin cattle station. He not only gained notoriety for his 'ride' but also as a horseman, bushman and horse breaker... the legend continues to this day.' The capitalisation and misspelling of Paterson's last name is as it appears in the text.

${ }^{23}$ Paul Ashton and Paula Hamilton, 'Places of the Heart: Memorials, Public History and the State in Australia Since 1960', Public History Review, vol 15, 2008, p14.

${ }^{24}$ Department of the Environment and Water Resources, Statement of Reasons For Decision Under Section 324F of The Environment Protection And Biodiversity Conservation Act 1999, Department of Environment and Water Resources (online). available:

http:// www.environment.gov.au/heritage/laws/publicdocuments/pubs /105840.doc (accessed 10 November 2006), np.

${ }^{25}$ Elyne Mitchell's Silver Brumby series comprises thirteen books which were published between 1958 and 1999. The Snowy Mountains Horse Riding Association based its submission on the National Heritage Criterion (h) which states that: 'the place has an outstanding heritage value to the nation because of the place's special association with the life or works of a person... of importance in Australia's history', in Department of the Environment and Water Resources, op cit.

${ }^{26}$ ibid, p20.

${ }^{27}$ ibid, p3.

${ }^{28}$ ibid, p4.

${ }^{29}$ Paul Connerton, How Societies Remember, Cambridge University Press, Cambridge, 1989, p72.

${ }^{30}$ ibid, p51.

${ }^{31}$ Other festivals focused on animals include the Pedigree Working Dog Australian Kelpie Muster at Casterton, Victoria. See the festival website (online). Available: http:// www.kelpies-

casterton.org/Main.asp? =Festival (accessed 12 February 2008); and the 
Man From Snowy River Bush Festival held in Corryong, Victoria. See the festival website (online). Available: http:// www.manfromsnowyriverbushfestival.com.au/ (accessed 12 February 2008).

${ }^{32}$ CSIRO Australia, CSIRO Fact Sheet: Bogong Moths, CSIRO Australia (online). Available: http:/ / www.csiro.au/resources/BogongMoths.html (accessed 21 February 2008).

${ }^{33}$ National Parks and Wildlife Service of New South Wales, Kociuszko National Park 2004 Draft Plan of Management, National Parks and Wildlife Service of New South Wales, Sydney, 2004, p66.

${ }^{34}$ CSIRO Australia, op cit.

${ }^{35}$ Bill McCormick, 'Bogong Moths and Parliament House', Parliament of Australia Research Brief Number 5, 31 October 2005 (online). Available: http:/ / wopared.parl.net/library/Pubs/RB/2005-06/06rb05.pdf (accessed 27 October 2006)

${ }^{36}$ ibid, p6.

${ }^{37}$ In the early 2000s the 'Bogong Moth Festival' was re-named the 'Ngan Girra Festival' meaning 'gathering place'. See River Murray Urban Users Committee, Bogong Moth Festival, River Murray Exhibition Fact Sheet Series (online). Available: http:// www.murrayusers.sa.gov.au/PDFs/02Bogong Moth Festival.pdf (accessed 3 November 2006).

${ }^{38}$ Ros Derrett, 'Festivals and regional Destinations: How Festivals Demonstrate a Sense of Community and Place', Rural Society, vol 13 no 1, 2003, pp35-53.

${ }^{39}$ Rev W. B. Clarke, 1852, quoted in Michael Young and Debbie and Ellen Mundy (comps), The Aboriginal People of the Monaro: A Documentary History, National Parks and Wildlife Service of New South Wales, Sydney, NSW, 2000, p173.

${ }^{40}$ This reservation was raised by some New South Wales National Parks and Wildlife Service staff in relation to the inclusion and use of Rev Clarke's accounts. See Independent Scientific Committee, An Assessment of the Values of Kosciuszko National Park, Australian Alps National Parks, Report funded and produced by National Parks and Wildlife Service of New South Wales, Sydney, 2004 (online). Available: http://www.australianalps.deh.gov.au/publications/index.html (accessed 10 November 2005), p135.

${ }^{41}$ Josephine Flood, The Moth Hunters: Aboriginal Prehistory of the Australian Alps, Australian Institute of Aboriginal Studies, Canberra, 1980.

${ }^{42}$ R. B. Good, Kosciusko Heritage: The Conservation Significance of Kosciusko National Park, National Parks and Wildlife Service of New South Wales, Sydney, 1992, p135.

${ }^{43}$ George Seddon, Searching for the Snowy: An Environmental History, Allen and Unwin, Sydney, 1994, pp115-121.

${ }^{44}$ Young and Mundy and Mundy, op cit, p197.

${ }^{45}$ Letter from Mr R. Forrester Payten to Albert Sherbourne Le Souef, 15 June 1949, quoted in ibid, p194.

${ }^{46}$ The letter in its entirety is presented in ibid, pp192-96. 
Public History Review I Searby

${ }^{47}$ Vince Bulger quoted in Kate Waters, Aboriginal Oral History Project:

Kosciuszko National Park, Project for the New South Wales Department of

Environment and Conservation, National Parks Service Southern

Directorate, Sydney, May 2004, p62. 